Analisis Kekerabatan Lengkeng Balitjestro -Prayanti, dkk Jurnal Pangan dan Agroindustri Vol.7 No.2: 53-59, April 2019

\title{
ANALISIS KEKERABATAN LENGKENG (Dimorcapus longan L.) BALITJESTRO BERDASARKAN KARAKTERISTIK PEMBUNGAAN DENGAN MARKA ISSR
}

\section{Genetic Relationship of Balitjestro Longan (Dimorcapus longan L.) Based on Flowering Characteristic by ISSR Markers}

\author{
Dwi Esti Prayanti1 ${ }^{1 *}$, Joni Kusnadi ${ }^{1}$, Baiq Dina Mariana ${ }^{2}$ \\ 1) Jurusan Teknologi Hasil Pertanian, FTP Universitas Brawijaya Malang \\ JI. Veteran, Malang 65145 \\ 2) Balai Penelitian Tanaman Jeruk dan Buah Subtropika \\ Jl. Raya Tlekung no.1, Junrejo, Batu 65301 \\ *Penulis Korespondensi, Email: dwiestip@gmail.com
}

\begin{abstract}
ABSTRAK
Pembungaan lengkeng pada umumnya dipacu suhu $15-22^{\circ} \mathrm{C}$. Lengkeng dapat diklasifikasikan berdasarkan respon pembungaannya terhadap suhu, yaitu mudah berbunga (sepanjang tahun dan ketika kebutuhan suhu tercapai) dan sulit berbunga (perlu induksi pembungaan). Penelitian ini bertujuan untuk menganalisis kekerabatan 12 aksesi lengkeng berdasarkan tiga karakter pembungaan dengan 12 marka ISSR (Inter Simple Sequence Repeats). Skoring data dilakukan berdasarkan hasil amplifikasi dan dianalisis menggunakan program NTSYS. Hasil penelitian menunjukkan bahwa tingkat kemiripan 12 aksesi lengkeng berkisar $65-94 \%$ dan terbagi dalam tiga kelompok. Kelompok pertama memiliki tingkat kemiripan 69.8-94\%, terdiri dari 5 aksesi yang mewakili karakter sulit berbunga (perlu induksi pembungaan). Kelompok kedua memiliki tingkat kemiripan 71.8-82.2\%, terdiri dari 5 aksesi yang mewakili karakter mudah berbunga (ketika kebutuhan suhu tercapai). Kelompok ketiga memiliki tingkat kemiripan $76.8 \%$, terdiri dari 2 aksesi yang mewakili karakter mudah berbunga (sepanjang tahun). Aksesi yang memiliki kekerabatan terdekat adalah $\mathrm{KL} 04$ dan $\mathrm{KL} 05$ dengan tingkat kemiripan 94\%. Marka ISSR yang digunakan berhasil mendeteksi kekerabatan lengkeng sesuai dengan karakter pembungaannya dengan baik.
\end{abstract}

Kata Kunci: ISSR, Kekerabatan, Pembungaan lengkeng

\section{ABSTRACT}

Flowering of longan is generally driven by the temperature of $15-22^{\circ} \mathrm{C}$. Longan can be classified based on the flowering responses to the temperature, which are easy to flower (throughout the year and when temperature requirement is reached) and difficult to flower (needs flowering induction). The aim of this research was to analyze the genetic relationship of 12 longan accessions based on three flowering characters by 12 ISSR (Inter Simple Sequence Repeats) markers. Data scoring was based on the results of amplification and analyzed using NTSYS program. The result showed that the similarity level of 12 longan accessions ranged $65-94 \%$ and divided into three groups. The similarity level of the first group was 69.8-94\%, consisted of 5 accessions representing the character of difficult to flower (needs flowering induction). The similarity level of the second group was $71.8-82.2 \%$, consisted of 5 accessions representing the character of easy to flower (when temperature requirement is reached). The similarity level of the third group was $76.8 \%$, consisted of 2 accessions representing the character of easy to flower (throughout the year). Accessions having the closest genetic relationship were KL 04 and KL 05 with 94\% of similarity level. In this research, ISSR markers were able to detect the genetic relationship of longan according to the flowering characters successfully.

Keywords: Genetic relationship, ISSR, Longan flowering 
Analisis Kekerabatan Lengkeng Balitjestro -Prayanti, dkk

Jurnal Pangan dan Agroindustri Vol.7 No.2: 53-59, April 2019

\section{PENDAHULUAN}

Lengkeng (Dimorcapus longan Lour) merupakan tanaman buah yang dapat tumbuh di daerah subtropis dan tropis, salah satunya di Indonesia. Pada awalnya, lengkeng yang berkembang di Indonesia adalah lengkeng yang hanya cocok ditanam pada dataran tinggi dengan pola curah hujan subtropis (Soenarso, 1990). Namun sekarang, hampir semua daerah di Indonesia dapat ditanami lengkeng, baik di dataran tinggi maupun dataran rendah (Tamura dkk, 2015).

Di Indonesia, permintaan buah lengkeng cenderung meningkat dari tahun ke tahun seiring dengan adanya perkembangan trend buah. Namun hal ini belum dapat dicapai karena produksi buah dalam negeri masih belum mencukupi kebutuhan, sehingga lengkeng diimpor dari Thailand dan China (Mariana dan Sugiyatno, 2013). Dengan meningkatnya jumlah penduduk dan dasar kebutuhan konsumsi buah minimum $32.5 \mathrm{~kg}$ buah/kapita/tahun, Indonesia membutuhkan persediaan buah-buahan sekitar 81250 juta kg/tahun. Namun, di Indonesia total produksi buah-buahan hanya sekitar 8000 juta kg/tahun (Tamura dkk, 2015).

Selain dengan impor, kebutuhan lengkeng dapat dipenuhi dengan cara meningkatkan produksi melalui budidaya lengkeng tanpa tergantung pada musim. Menurut Verheij and Coronel (1992), lengkeng membutuhkan suhu dingin sekitar $15-22^{\circ} \mathrm{C}$ untuk memacu pembungaan. Daerah sebaran tanaman lengkeng mayoritas berada di Pulau Jawa yang memiliki pola curah hujan subtropis, sehingga menyebabkan budidaya lengkeng terbatas pada daerah tertentu (Sugiyatno dan Mariana, 2006). Dengan adanya hal tersebut, lengkeng dapat diklasifikasikan berdasarkan kemudahannya untuk berbunga karena pengaruh musim atau suhu.

Penelitian ini bertujuan untuk menganalisis kekerabatan 12 aksesi lengkeng berdasarkan karakteristik pembungaannya dengan 12 marka ISSR (Inter Simple Sequence Repeats). Informasi kekerabatan lengkeng berdasarkan karakteristik pembungaannya, berguna untuk program pemuliaan lengkeng yang efisien. ISSR merupakan salah satu marka molekuler PCR based techniques yang tidak membutuhkan sekuen spesifik (Zulfahmi, 2013). ISSR mampu mendeteksi lebih sensitif diversitas genetik pada tingkatan rendah (Narayanan et al., 2007). ISSR memiliki reproduksibilitas tinggi dan efisiensi yang tinggi untuk menghasilkan polimorfisme. ISSR dapat digunakan untuk analisis filogenetik, finger printing, analisis struktur populasi, identifikasi varietas, pemetaan genetik, dan seleksi marker (Vijayan, 2005). Marka ISSR telah terbukti mampu mengidentifikasi keragaman genetik tanaman, seperti lengkeng (Mariana dkk, 2011), stroberi (Debnath et al., 2008), mentimun (Singh et al., 2016), dan lain sebagainya.

\section{BAHAN DAN METODE}

\section{Bahan}

Penelitian dilakukan di Laboratorium Balai Penelitian Tanaman Jeruk dan Buah Subtropika (Balitjestro) pada bulan Juli hingga Agustus 2018. Bahan utama yang digunakan adalah 12 daun muda aksesi lengkeng koleksi Balitjestro (Tabel 1). Bahan yang digunakan untuk analisis adalah 12 primer ISSR, PVP (Panreac), NaCl (Univar), $\beta$-merkaptoetanol (Merck), CTAB (Panreac), NaOH (Panreac), kloroform (Merck), isoamilalkohol (Merck), sodium asetat (Univar), asam borat (Emsure), isopropanol (Merck), etanol (Merck), tris base (Vivantis), EDTA (Merck), RNAse A (Thermo Scientific), Dream Taq Green PCR Master Mix (Thermo Scientific), water nuclease-free (Thermo Scientific), agarosa (Vivantis), ethidium bromide (Thermo Scientific), loading dye (Thermo Scientific), lambda (Promega), DNA ladder (Thermo Scientific), akuades. 
Analisis Kekerabatan Lengkeng Balitjestro -Prayanti, dkk Jurnal Pangan dan Agroindustri Vol.7 No.2: 53-59, April 2019

Tabel 1. Aksesi lengkeng koleksi Balitjestro

\begin{tabular}{|c|c|c|c|}
\hline No & Nama aksesi & Asal & Keterangan \\
\hline 1 & KL 01 & Batu & Lokal: berbunga setahun sekali \\
\hline 2 & Selarong & Yogyakarta & Lokal: berbunga setahun sekali \\
\hline 3 & $\mathrm{KL} 03$ & Jawa Tengah & Lokal: berbunga setahun sekali \\
\hline 4 & KL 04 & Blitar & Lokal: berbunga setahun sekali \\
\hline 5 & KL 05 & Purworejo & Lokal: berbunga setahun sekali \\
\hline 6 & Diamond river & & Introduksi: berbunga sendiri kapan saja \\
\hline 7 & Pingpong & & Introduksi: berbunga sendiri kapan saja \\
\hline 8 & $\mathrm{KL} 08$ & Malang & $\begin{array}{l}\text { Introduksi (Aroma durian) : berbunga } \\
\text { sendiri kapan saja }\end{array}$ \\
\hline 9 & Kristal & & Introduksi: berbunga sendiri kapan saja \\
\hline 10 & KL 09 & Jawa Tengah & $\begin{array}{l}\text { Introduksi: butuh perlakuan untuk } \\
\text { inisiasi pembungaan }\end{array}$ \\
\hline 11 & Itoh & & $\begin{array}{l}\text { Introduksi: butuh perlakuan untuk } \\
\text { inisiasi pembungaan }\end{array}$ \\
\hline 12 & Kateki & & $\begin{array}{l}\text { Introduksi: butuh perlakuan untuk } \\
\text { inisiasi pembungaan }\end{array}$ \\
\hline
\end{tabular}

\section{Alat}

Alat yang digunakan adalah mesin PCR (Eppendorf vapo.protect), set elektroforesis DNA (BIO-RAD), BioDocAnalyze (BIO-RAD Gel Doc $\left.{ }^{T M} E Q\right)$, centrifuge (Thermo Scientific, Eppendorf), mini spin (Eppendorf), laminar air flow (LabTech), lemari asam (Fumhood), vortex (Hwashin), water bath (Mammert), pH meter (Mettler Toledo), lemari beku (Sansio), mikrotube (Axygen), mikrotip (Axygen), mikropipet (Vitlab, Lambda), timbangan analitik (Pioneer ${ }^{\mathrm{TM}}$ ), glassware, mortar.

\section{Ekstraksi dan Uji Kualitas DNA Lengkeng}

Tanaman lengkeng mengandung banyak polisakarida, polifenol, serta metabolit sekunder lainnya yang dapat menghambat proses ekstraksi DNA dan proses PCR. Oleh sebab itu perlu dilakukan suatu optimasi untuk memaksimalkan proses ekstraksi DNA lengkeng.

Ekstraksi DNA dilakukan dengan modifikasi metode Sahu et al. (2012). (1) 0.1 gram daun muda aksesi lengkeng yang telah disimpan pada suhu $-20^{\circ} \mathrm{C}$, digerus dengan bubuk PVP secukupnya dan $1 \mathrm{ml}$ bufer CTAB menggunakan mortar steril. (2) Dimasukkan ke dalam tube $2 \mathrm{ml}$ dan ditambahkan $20 \mu \mathrm{l}$ merkaptoetanol. (3) Tube dibolak-balik, lalu diinkubasi selama 30 menit pada suhu $65^{\circ} \mathrm{C}$ (setiap 5 menit dibolak-balik). (4) Ditambahkan 1/10 volume Na-asetat dan 2x volume kloroform:isoamil alkohol $(24: 1, \mathrm{v} / \mathrm{v})$ ke dalam tube lalu dibolak-balik. (5) Disentrifugasi 12500 rpm selama 15 menit. Apabila bagian fase atas masih belum bening, maka ditambahkan lagi kloroform:isoamil alkohol dan disentrifugasi lagi hingga berwarna bening. (6) Fase atas dipindahkan ke tube $1.5 \mathrm{ml}$. (7) Ditambahkan 2x volume isopropanol dingin lalu dimasukkan dalam lemari beku selama 1 jam. (8) Disentrifugasi 12000 rpm selama 15 menit. (9) Supernatan dibuang, pelet dicuci dengan etanol dingin $70 \%$ lalu disentrifugasi 12000 rpm selama 15 menit. (10) Supernatan dibuang, pelet dikeringkan di LAF. (11) Pelet ditambahkan $300 \mu$ larutan bufer TE dan $2 \mu$ RNase lalu diinkubasi ada suhu $37^{\circ} \mathrm{C}$ selama 30 menit. (12) Ditambahkan 1/10 volume Na-asetat dan $300 \mu \mathrm{l} \mathrm{kloroform:isoamil} \mathrm{alkohol} \mathrm{(24:1,}$ $\mathrm{v} / \mathrm{v}$ ) ke dalam tube lalu disentrifugasi $12000 \mathrm{rpm}$ selama 15 menit. (13) Fase atas dipindahkan ke tube $1.5 \mathrm{ml}$. (14) Ditambahkan 1x volume etanol dingin 70\%. (15) Disentrifugasi $12000 \mathrm{rpm}$ selama 15 menit. (16) Supernatan dibuang, pelet dikeringkan di LAF lalu dilarutkan dengan $100 \mu$ l bufer TE.

Setelah ekstraksi DNA, dilakukan uji kualitas menggunakan elektroforesis dengan konsentrasi agarosa $0.8 \%$ mengikuti modifikasi metode Agisiminto dkk (2007). Selanjutnya dilarutkan dalam larutan TBE 0.5x dan dialirkan pada tegangan listrik $50 \mathrm{~V}$ selama 30 menit. Hasil elektroforesis difoto menggunakan BioDocAnalyze BIO-RAD Gel Doc ${ }^{T M} E Q$. 


\section{Amplifikasi dan Elektroforesis DNA Lengkeng}

Amplifikasi DNA dengan PCR-ISSR diprogram mengikuti modifikasi metode Pujiastuti (2012). Campuran PCR terdiri dari $4 \mu$ sampel DNA tiap aksesi lengkeng, $8 \mu \mathrm{l}$ taq green PCR Master Mix, $3 \mu \mathrm{l}$ primer, $1 \mu \mathrm{l}$ water nuclease-free. Campuran reaksi PCR selanjutnya di spindown 6 rpm selama 45 detik, lalu di running pada mesin PCR dengan 35 siklus.

Tabel 2. Proses PCR

\begin{tabular}{lcc}
\hline \multicolumn{1}{c}{ Proses } & Suhu & Waktu \\
\hline Inisial denaturasi & $94^{\circ} \mathrm{C}$ & 5 menit \\
Denaturasi & $94^{\circ} \mathrm{C}$ & 1 menit \\
Annealing & $55^{\circ} \mathrm{C}$ & 1.5 menit \\
Ekstensi & $72^{\circ} \mathrm{C}$ & 2 menit \\
Final ekstensi & $72^{\circ} \mathrm{C}$ & 5 menit \\
Cooling & $4^{\circ} \mathrm{C}$ & \\
\hline
\end{tabular}

Setelah dilakukan amplifikasi DNA dengan PCR-ISSR, hasil amplifikasi dielektroforesis dengan konsentrasi agarosa 1.2\% mengikuti modifikasi metode Pujiastuti (2012). Selanjutnya dilarutkan dalam larutan TBE $0.5 \mathrm{x}$ dan dialirkan pada tegangan listrik $50 \mathrm{~V}$ selama 90 menit. Hasil elektroforesis difoto menggunakan BioDocAnalyze BIO-RAD Gel Doc ${ }^{T M} E Q$.

\section{Analisis data}

Data yang didapat didasarkan pada hasil kualitatif. Secara kualitatif, data diperoleh dengan melihat pita amplifikasi menggunakan gel documentation dan data dari skoring pita hasil amplikasi. Pita akan diklasifikasikan "1" apabila terdapat pita hasil amplifikasi dan "0" apabila tidak terdapat pita hasil amplifikasi. Data selanjutnya dianalisis dengan analisis klaster unweighted pair-group method arithmetic averages (UPGMA) menggunakan metode SAHN, lalu divisualisasikan menggunakan program NTSYS-pc (Numerical Taxonomy and Multivariate Analysis System, Version 2.20).

\section{HASIL DAN PEMBAHASAN}

\section{Ekstraksi dan Uji Kualitas DNA Lengkeng}

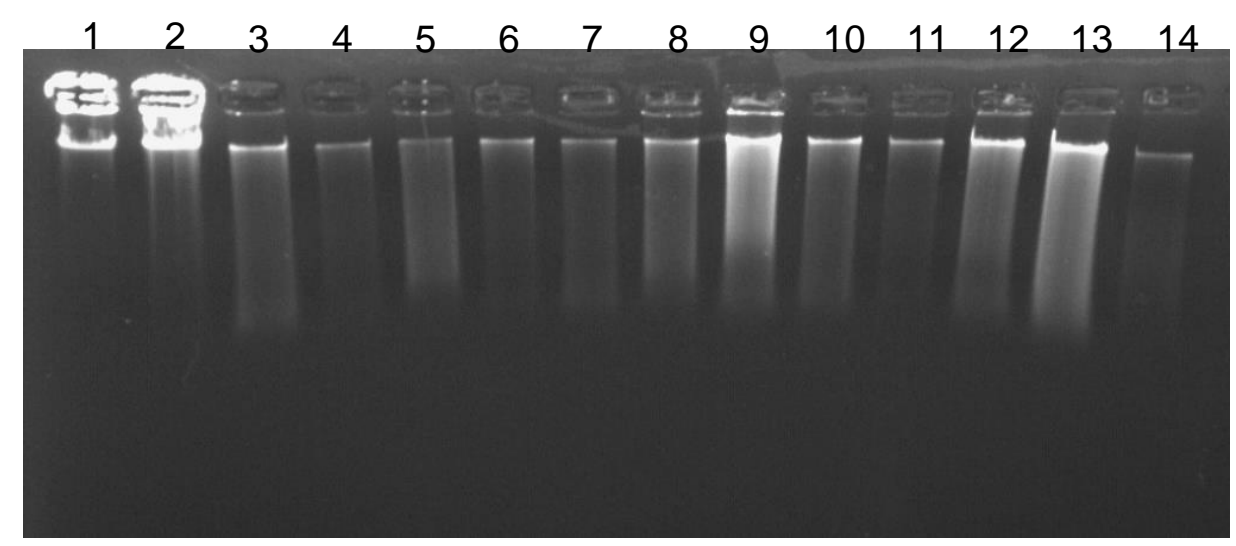

Gambar 1. Hasil Ekstraksi 12 Sampel DNA Lengkeng

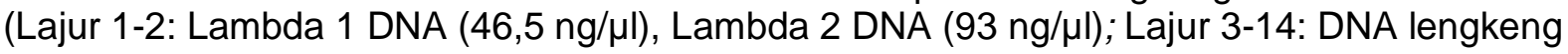
KL 01, Selarong, KL 03, KL 04, KL 05, Diamond river, Pingpong, KL 08, KL 09, Itoh, Kristal, Kateki)

Hasil visualisasi DNA secara kualitas menggunakan gel documentation menunjukkan masih adanya pita yang "smear". Hal ini terjadi karena DNA masih kurang murni dan terdapat kontaminasi, seperti polisakarida, fenol, protein, atau RNA (Qiagen, 2005). PCR-ISSR tidak 
memerlukan kemurnian DNA yang terlalu tinggi, namun membutuhkan suatu proses untuk meminimalkan senyawa pengotor yang dapat menghambat proses PCR seperti polisakarida (Hariyati, 2013). Secara kuantitas, proses PCR-ISSR hanya membutuhkan konsentrasi DNA yang tidak terlalu besar, yaitu 10-50 ng. Konsentrasi DNA $10 \mathrm{ng}$ mampu menghasilkan produk amplifikasi yang setara dengan konsentrasi DNA 25 atau $50 \mathrm{ng}$ per $20 \mu \mathrm{l}$ reaksi PCR (Reddy et al., 2002)

\section{Amplifikasi dan Elektroforesis DNA Lengkeng}

Jumlah pola pita DNA yang dihasilkan setiap primer berkisar antara 10-20 (Tabel 3). Primer ISSR 6 menghasilkan jumlah pita paling banyak yaitu 20 pita, namun primer yang menunjukkan polimorfisme paling tinggi adalah primer LN 10, LN 22, dan ISSR 1 dengan persentase polimorfisme $100 \%$. Ketiga primer tersebut merupakan primer yang paling kuat mendeteksi perbedaan/polimorfisme pada tiap aksesi. Primer LN 8, LN 9, LN 13, ISSR 2, ISSR 4, ISSR 5, ISSR 6, ISSR 7 memiliki persentase minimal 90\%. Primer-primer tersebut dapat digunakan untuk mendeteksi kekerabatan lengkeng dengan baik.

Tabel 3. Tingkat polimorfisme marka ISSR berdasarkan pola pita

\begin{tabular}{|c|c|c|c|c|}
\hline Primer & $\begin{array}{c}\text { Sekuen nukleotida } \\
\left(5^{\prime}-3^{\prime}\right)\end{array}$ & $\begin{array}{l}\text { Jumlah pita } \\
\text { polimorfik }\end{array}$ & $\begin{array}{l}\text { Jumlah pita } \\
\text { monomorfik }\end{array}$ & $\begin{array}{l}\text { Persentase } \\
\text { polimorfisme }\end{array}$ \\
\hline LN 8 & $(\mathrm{GA})_{9} \mathrm{~A}$ & 12 & 1 & $92.31 \%$ \\
\hline LN 9 & $(\mathrm{GA})_{9} \mathrm{C}$ & 11 & 1 & $91.67 \%$ \\
\hline LN 10 & $(\mathrm{GA})_{9} \mathrm{~T}$ & 19 & 0 & $100 \%$ \\
\hline LN 11 & $\operatorname{CCGGATCC}(G A)_{9}$ & 9 & 3 & $75 \%$ \\
\hline LN 13 & CCGGATCC $(\mathrm{GT})_{9}$ & 17 & 1 & $94.44 \%$ \\
\hline LN 22 & GATC $(\text { GTAG })_{7}$ & 16 & 0 & $100 \%$ \\
\hline ISSR 1 & $\mathrm{HVH}(\mathrm{CA})_{7}$ & 16 & 0 & $100 \%$ \\
\hline ISSR 2 & $(\mathrm{AC})_{8} \mathrm{YA}$ & 9 & 1 & $90 \%$ \\
\hline ISSR 4 & $\mathrm{HVH}(\mathrm{TCC})_{8}$ & 15 & 1 & $93.75 \%$ \\
\hline ISSR 5 & $(\mathrm{TCC})_{5} \mathrm{RY}$ & 10 & 1 & $90.91 \%$ \\
\hline ISSR 6 & $\mathrm{BDB}(\mathrm{TCC})_{5}$ & 19 & 1 & $95 \%$ \\
\hline ISSR 7 & $(\mathrm{GT})_{8} \mathrm{YC}$ & 9 & 1 & $90 \%$ \\
\hline
\end{tabular}

\section{Kekerabatan 12 aksesi lengkeng}

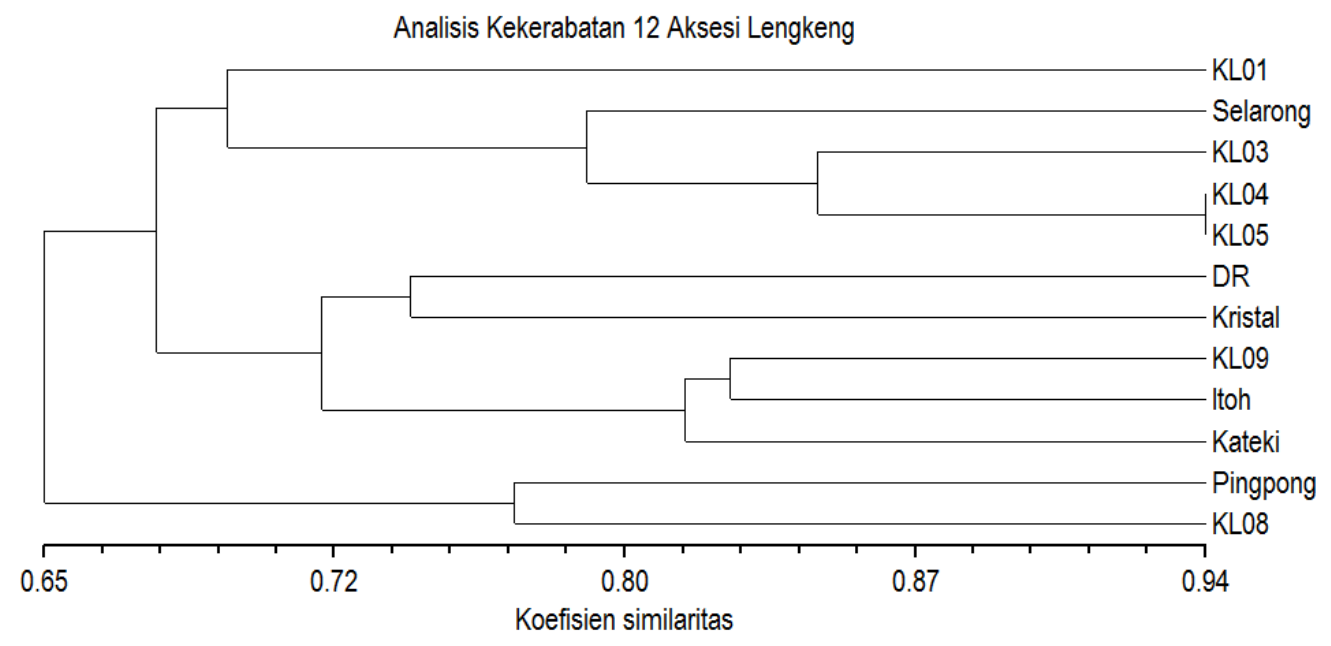

Gambar 2. Dendrogram Lengkeng

Dari gambar 2 dapat diketahui bahwa 12 aksesi lengkeng tersebut menunjukkan tingkat kemiripan sebesar 65-94\%. Menurut Tjitrosoepomo (2013), tingkat kemiripan berkisar antara 
0\% (tidak ada kemiripan) hingga 100\% (identik). 12 aksesi lengkeng ini terbagi menjadi tiga kelompok. Kelompok pertama terdiri dari 5 aksesi (KL 01, Selarong, KL 03, KL 04, KL 05) dengan tingkat kemiripan 69.8-94\% yang mewakili karakter sulit berbunga (perlu induksi pembungaan). Kelompok kedua terdiri dari 5 aksesi (Diamond river, Kristal, KL 09, Itoh, Kateki) dengan tingkat kemiripan 71.8-82.2\% yang mewakili karakter mudah berbunga (ketika kebutuhan suhu tercapai). Kelompok ketiga terdiri dari 2 aksesi (Pingpong dan KL 08) dengan tingkat kemiripan $76.8 \%$ yang mewakili karakter mudah berbunga (sepanjang tahun). Kekerabatan ini menunjukkan adanya keragaman genetik yang luas yang dapat digunakan untuk modal perbaikan varietas lengkeng guna menghasilkan varietas baru (Mariana dan Sugiyatno, 2013).

\section{SIMPULAN}

Dari hasil penelitian yang telah dilakukan, dapat diambil kesimpulan bahwa primer ISSR yang menunjukkan tingkat polimorfisme paling tinggi adalah primer $L N 10$, LN 22, dan ISSR 1 dengan persentase polimorfisme 100\%. Primer LN 8, LN 9, LN 13, ISSR 2, ISSR 4, ISSR 5, ISSR 6, ISSR 7 memiliki persentase minimal 90\%, yang berarti primer-primer tersebut dapat digunakan untuk mendeteksi kekerabatan lengkeng dengan baik.

12 aksesi lengkeng menunjukkan tingkat kemiripan sebesar $65-94 \%$ dan terbagi menjadi tiga kelompok. Kelompok pertama terdiri dari 5 aksesi (KL 01, Selarong, KL 03, KL 04, KL 05) dengan tingkat kemiripan 69.8-94\% \% yang mewakili karakter sulit berbunga (perlu induksi pembungaan). Kelompok kedua terdiri dari 5 aksesi (Diamond river, Kristal, KL 09, Itoh, Kateki) dengan tingkat kemiripan $71.8-82.2 \%$ yang mewakili karakter mudah berbunga (ketika kebutuhan suhu tercapai). Kelompok ketiga terdiri dari 2 aksesi (Pingpong dan KL 08) dengan tingkat kemiripan $76.8 \%$ yang mewakili karakter mudah berbunga (sepanjang tahun). Aksesi yang memiliki kekerabatan terdekat adalah $\mathrm{KL} 04$ dan $\mathrm{KL} 05$ dengan tingkat kemiripan $94 \%$.

\section{UCAPAN TERIMAKASIH}

Penulis mengucapkan terimakasih kepada Balai Penelitian Tanaman Jeruk dan Buah Subtropika (balitjestro) atas ketersediaan tempat dan biaya untuk penelitian ini.

\section{DAFTAR PUSTAKA}

Agisimanto, D., C. Matyasari dan A. Supriyanto. 2007. Perbedaan Primer RAPD dan ISSR dalam Identifikasi Hubungan Kekerabatan Genetik Jeruk Siam (Citrus suhuniensis L. Tan) Indonesia. Jurnal Hortikultura 17:2, 101-110

Debnath, S.C., S. Khanizadeh, A.R. Jamieson and C. Kempler. 2008. Inter Simple Sequence Repeat (ISSR) Markers to Assess Genetic Diversity and Relatedness within Strawberry Genotypes. Canadian Journal of Plant Science 88:2, 313-322

Hariyati, T. 2013. Analisis Genetik Durian Hibrida Hasil Persilangan Durio kutejensis dan Durio zibethinus Murr Berdasarkan Penanda RAPD (Random Amplified Polymorphic DNA). Tesis. Fakultas Teknologi Pertanian, Universitas Brawijaya. Malang

Mariana, B.D. dan A. Sugiyatno. 2013. Keragaman Morfologi dan Genetik Lengkeng di Jawa Tengah dan Jawa Timur. Informatika Pertanian 22:2, 95-102

Mariana, B.D., A. Sugiyatno dan A. Supriyanto. 2011. Genetic Diversity of Local Accessions of Dimorcapus longan Revealed by ISSR Markers. Buletin Plasma Nutfah 17, 25-29

Narayanan, C., S.A. Wali., N. Shukla., R. Kumar., A.K. Mandal and S.A. Ansari. 2007. RAPD and ISSR Markers for Molecular Characterization of Teak (Tectona Grandis) Plus Trees. Journal of Tropical Forest Science 4, 218-225

Pujiastuti, R. 2012. Keragaman Beberapa Aksesi Lengkeng (Dimorcapus longan Lour.) berdasarkan Karakter Morfologi dan Penanda RAPD. Skripsi. Fakultas Pertanian, Universitas Brawijaya. Malang

Qiagen. 2005. Hotstar Taq PCR Handbook. Qiagen. Germany 
Reddy, M.P., N. Sarla and E.A. Siddiq. 2002. Inter Simple Sequence Repeat (ISSR) Polymorphism and Its Application in Plant Breeding. Euphytica 128, 9-17

Sahu, S.K., M. Thangaraj and K. Kathiresan. 2012. DNA Extraction Protocol for Plants with High Levels of Secondary Metabolites and Polysaccharides without Using Liquid Nitrogren and Phenol. Molecular Biology, 1-6

Singh, D.K., R. Tewari, Singh N.K. and S.S. Singh. 2016. Genetic Diversity Cucumber using Inter Simple Sequence Repeats (ISSR). Transcriptomics (Doi: 10.4172/23298936.1000129)

Soenarso. 1990. Laporan Penelitian Studi Keragaman Klon Lengkeng dan Leci serta Penyebarannya di Jawa dan Bali. Sub Balai Penelitian Hortikultura Tlekung

Sugiyatno, A. dan B.D. Mariana. 2006. Karakteristik Lengkeng Dataran Rendah. Iptek Hortikultura 2, 29-33

Tamura, M.D., L. Setyobudi dan Y.B.S Heddy. 2015. Variasi Jenis dan Kultivar Lengkeng (Nephellium longan L.) Unggulan di Kecamatan Poncokusumo Kabupaten Malang. Jurnal Produksi Tanaman 3:7, 535-541

Tjirosoepomo, G. 2013. Taksonomi Tumbuhan Obat-Obatan. Gajah Mada University Press. Yogyakarta

Verheij, E.W.M. and R.E. Coronel. 1992. Edible Fruit and Nuts. Plant Resources of South East Asia 2, 146-151

Vijayan, K. 2005. Inter Simple Sequence Repeat (ISSR) Polymorphism and Its Application in Mulberry Genom Analysis. International Journal Indust. Entomol 10, 79-86

Zulfahmi. 2013. Penanda DNA untuk Analisis Genetik Tanaman. Jurnal Agroteknologi 2, 4152 